\title{
Anti-rhesus D prophylaxis in pregnant women is based on
}

\section{sialylated IgG antibodies [version 1; peer review: 2 approved]}

\author{
André Winkler ${ }^{1,2}$, Markus Berger ${ }^{3}$, Marc Ehlers ${ }^{1,2}$ \\ ${ }^{1}$ Laboratory of Tolerance and Autoimmunity, German Rheumatism Research Center (DRFZ), Leibniz Institute, Berlin, 10117, \\ Germany \\ 2Laboratory of Tolerance and Autoimmunity, Institute for Systemic Inflammation Research, University of Luebeck, Luebeck, 23538, \\ Germany \\ 3Laboratory of Glycodesign and Glycoanalytics, Institute for Laboratory Medicine, Clinical Chemistry and Pathobiochemistry, Charité \\ - University Medicine Berlin, Berlin, 10117, Germany
}

V1 First published: 09 Aug 2013, 2:169
https://doi.org/10.12688/f1000research.2-169.v1

Latest published: 09 Aug 2013, 2:169

https://doi.org/10.12688/f1000research.2-169.v1

\section{Abstract}

Red blood cells (RBCs) from a rhesus $D(R h D)$-positive fetus that reach the bloodstream of an RhD-negative pregnant woman during birth can induce a pathogenic antibody (Ab) response against the RhDpositive RBCs, leading to fetal hemolytic disease in subsequent pregnancies. To prevent a pathogenic immune reaction, the RhDnegative mother receives serum immunoglobulin $G$ (IgG) containing polyclonal RhD-specific IgG Abs that is purified from healthy RhDnegative men immunized with RhD-positive RBCs. However, the protective mechanism of these polyclonal RhD-specific IgG Abs is unclear. It has become increasingly clear that the effector function of IgG Abs is regulated by the glycan pattern linked to the Fc region of IgG Abs. Non-fucosylated (afucosylated) IgG Abs have a higher affinity for activating Fc gamma receptors, and thus induce a stronger Abdependent cellular cytotoxicity (ADCC) reaction than do fucosylated IgG Abs. Agalactosylated and asialylated, autoantigen-specific serum IgG Abs correlate with pro-inflammatory immune responses and disease activity in patients with rheumatoid arthritis. In contrast, galactosylated and sialylated IgG Abs are immunosuppressive and inhibit in form of immune complexes (ICs) dendritic cell (DC) maturation and pro-inflammatory $T$ and $B$ cell immune responses in an antigen-specific manner. However, the galactosylation and sialylation levels of the protective polyclonal RhD-specific IgG Abs are unknown. Here, we purified RhD-specific IgG Abs from the approved commercial product Rhophylac ${ }^{\circledR}$ (CSL Behring) and found that these RhD-specific IgG Abs were even more galactosylated and sialylated than the total Rhophylac $\circledast$ IgG Abs. This result suggests that these galactosylated and sialylated polyclonal RhD-specific IgG Abs are immunosuppressive and induce tolerance against $\mathrm{RhD}$, which would be in strong contrast to a low fucosylated, low galactosylated and low sialylated monoclonal RhD-specific IgG Ab developed to prevent fetal

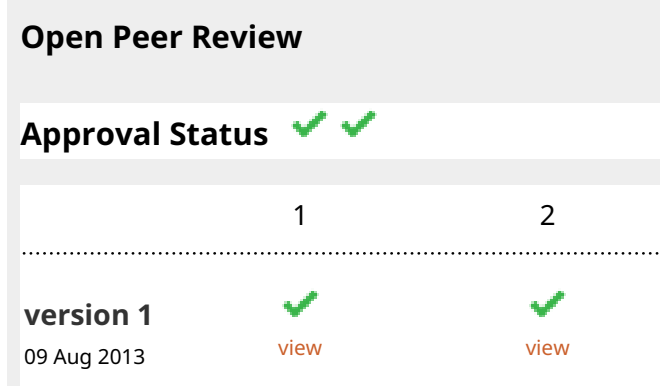

1. Tracy McGaha, Georgia Regents University Cancer Center, Augusta, GA, USA

2. Mikael C. I. Karlsson, Karolinska Institutet, Karolinska University Hospital Solna, Stockholm, Sweden

Any reports and responses or comments on the article can be found at the end of the article. 
hemolytic disease that has recently passed a clinical phase II study.

Corresponding author: Marc Ehlers (marc.ehlers@uk-sh.de)

Competing interests: No competing interests were disclosed.

Grant information: AW and ME were supported by the German Research Foundation (DFG: EH221-5 and SFB/TR654 project C9). In addition ME was a fellow of the Claussen-Simon-Foundation, and supported by the Max Planck Institute for Infection Biology, Berlin, Germany and by additional DFG grants (RTG1727 associated project 16, IRTG1911 project A4 and the cluster of excellence 306

"Inflammation at Interfaces" project K-TP2). MB was supported by the German Ministry of Research and Education (03IP511) and the Sonnefeld Foundation.

The funders had no role in study design, data collection and analysis, decision to publish, or preparation of the manuscript.

Copyright: ( 2013 Winkler A et al. This is an open access article distributed under the terms of the Creative Commons Attribution License, which permits unrestricted use, distribution, and reproduction in any medium, provided the original work is properly cited. Data associated with the article are available under the terms of the Creative Commons Zero "No rights reserved" data waiver (CC0 1.0 Public domain dedication).

How to cite this article: Winkler $A$, Berger $M$ and Ehlers $M$. Anti-rhesus $D$ prophylaxis in pregnant women is based on sialylated IgG antibodies [version 1; peer review: 2 approved] F1000Research 2013, 2:169 https://doi.org/10.12688/f1000research.2-169.v1

First published: 09 Aug 2013, 2:169 https://doi.org/10.12688/f1000research.2-169.v1 


\section{Introduction}

Red blood cells (RBCs) from a rhesus D (RhD)-positive fetus that get in contact with immune cells of an $\mathrm{RhD}$-negative pregnant woman during birth can induce a pathogenic antibody $(\mathrm{Ab})$ response against the RhD-positive RBCs, leading to fetal hemolytic disease in subsequent pregnancies with $\mathrm{RhD}$-positive fetuses after transplacental passage. To prevent allo-immunization by $\mathrm{RhD}$-positive fetal RBCs, the RhD-negative mother receives one prenatal and one postnatal injection of serum immunoglobulin $\mathrm{G}(\mathrm{IgG})$ containing polyclonal $\mathrm{RhD}$-specific $\mathrm{IgG}$ Abs that is purified from healthy RhD-negative men immunized with RhD-positive RBCs. Such a passive anti-RhD $\operatorname{IgG~Ab}$ treatment i) induces a rapid clearance of RhD-positive RBCs from the bloodstream of the mother and ii) inhibits the development of pathogenic anti-RhD Abs by the mother ${ }^{1}$.

However, the protective mechanism of passive anti-RhD treatment remains unclear. It is hypothesized that the clearance of $\mathrm{RhD}$-positive RBCs is mediated through an $\mathrm{Fc} \gamma$ receptor $(\mathrm{Fc} \gamma \mathrm{R})$ IIIA-mediated Ab-dependent cellular cytotoxicity (ADCC) reaction and that rapid clearance prevents immunization ${ }^{1-4}$. To prevent immunization, it has also been suggested that polyclonal anti-RhD IgG Abs have to inhibit the activation of $\mathrm{RhD}$-specific $\mathrm{B}$ cells through the co-ligation of the $\mathrm{B}$ cell receptor and an inhibitory receptor, such as the IgG inhibitory receptor Fc $\gamma \mathrm{RIIB}^{2,3}$. Furthermore, tolerance induction via antigen-presenting cells (APCs) has been posited to inhibit pro-inflammatory, RhD-specific $\mathrm{T}$ cell respons$\mathrm{es}^{2,5,6}$. However, it is questionable whether Fc $\gamma$ RIIIA crosslinking on APCs inhibits pro-inflammatory $\mathrm{RhD}$-specific $\mathrm{T}$ cell responses but rather enforces pro-inflammatory $\mathrm{T}$ cell responses ${ }^{7}$. It is more likely that polyclonal anti-RhD IgG Abs target an inhibitory receptor (complex) on APCs to induce regulatory $\mathrm{T}$ cells and tolerance for inhibiting pro-inflammatory $\mathrm{T}$ cell and therewith also $\mathrm{T}$ celldepemdent B cell responses.

Attempts to substitute this polyclonal anti-RhD IgG prophylaxis with RhD-specific monoclonal IgG Abs have failed because the monoclonal $\mathrm{RhD}$-specific IgG Abs were relatively unstable due to intramolecular rearrangements or did not clear RhD-positive RBCs as rapidly as the available polyclonal anti-RhD IgG Abs in in vitro assays or clinical trials and/or did not sufficiently inhibit allo-immunization in clinical trials ${ }^{1,4,8}$.

It has become increasingly clear that the effector function of IgG Abs is highly regulated by the Abs' Fc N-linked glycosylation pattern (Figure 1A). Non-fucosylated (afucosylated) IgG Abs have a higher affinity for activating Fc $\gamma R$ s, such as Fc $\gamma$ RIIIA, and thus induce a stronger ADCC reaction than do fucosylated $\operatorname{IgG} \mathrm{Abs}^{9,10}$. This finding is currently translated, for example, into tumor-specific $\mathrm{Ab}$ therapy.

Agalactosylated and asialylated (G0), autoantigen-specific serum IgG Abs correlate with pro-inflammatory immune responses and disease activity in patients with rheumatoid arthritis (RA) ${ }^{11-14}$. In contrast, pregnancy-induced and anti-tumor necrosis factor (TNF) therapy-induced remission in RA patients is associated with an increase in galactosylated and sialylated IgG Abs ${ }^{15,16}$. In this context, an anti-inflammatory role has been suggested for sialylated IgG Abs. Accordingly, the sialylated IgG subfraction of intravenous IgG (IVIG), which is purified from pooled human plasma from healthy donors and used to systemically treat autoimmunity in high doses $(2 \mathrm{~g} / \mathrm{kg})$, exhibits anti-inflammatory activity ${ }^{17-20}$. We have recently shown that low doses of immune complexes (ICs) containing sialylated antigen-specific IgG Abs inhibit dendritic cell maturation and pro-inflammatory $\mathrm{T}$ and $\mathrm{B}$ cell immune responses in an antigen-specific manner ${ }^{21-23}$. ICs containing $15 \%$, but not $5 \%$, sialylated IgG Abs have further been sufficient to inhibit B cell activation in vitro ${ }^{23}$. Furthermore, it has recently been shown that ICs containing galactosylated, but not sialylated, IgG Abs are already sufficient to inhibit neutrophil activation ${ }^{24}$.

Thus, G0 IgG Abs enhance, whereas galactosylated and sialylated IgG Abs suppress, pro-inflammatory immune responses. Accordingly, ICs containing galactosylated and sialylated IgG Abs inhibit rather than induce an ADCC reaction by at least reduced binding affinity of galactosylated and sialylated IgG Abs to FcyRIIIA ${ }^{17,25}$ but also likely by active suppression mechanisms via inhibitory receptors on immune cells.

However, based on the assumption that anti-RhD IgG Abs clear $\mathrm{RhD}$-positive RBCs through an ADCC reaction, the different outcomes of monoclonal anti-RhD IgG Abs have been particularly attributed to different levels of fucose $\mathrm{e}^{1,2,4,26-29}$. By contrast, the role of anti-RhD IgG galactosylation and sialylation has hardly been investigated.

Based on the idea that anti-tumor as well as anti-RhD IgG Abs should induce a strong ADCC response by recruiting Fc $\gamma$ RIIIAexpressing immune cells, the French biotechnology company Laboratoire Francais du Fractionnement et des Biotechnologies (LFB; Les Ulis, France) has generated a monoclonal anti-CD20 IgG1 Ab (ublituximab; LFB-R603) and a human monoclonal RhD-specific IgG1 Ab (roledumab, LFB-R593 $3^{30}$ ) with low Fc fucosylation, low Fc galactosylation and low Fc sialylation based on their patent ${ }^{31}$. In the meantime the company has performed clinical phase $\mathrm{I}^{32}$ and II (NCT00952575; completed 2011) studies on roledumab ${ }^{33}$. The phase II study was designed to demonstrate the ability of roledumab to effectively eliminate exogenously administered RhD-positive $\mathrm{RBCs}$ from the circulation of an $\mathrm{RhD}$-negative individual, thereby preventing $\mathrm{RhD}$ allo-immunization. The results have not been published yet.

However, based on the findings described above regarding the effector functions of differentially glycosylated IgG Abs, it is questionable whether an anti-tumor IgG1 $\mathrm{Ab}$ and an anti-RhD IgG1 Ab should have the same Fc glycosylation. Whether low-galactosylated, low-sialylated RhD-specific IgG Abs can inhibit the induction of pathogenic immune reactions against $\mathrm{RhD}$-positive fetal $\mathrm{RBCs}$ or rather enhance allo-immunization is also questionable. To identify the Fc galactosylation and sialylation of RhD-specific IgG Abs in a commercially available polyclonal anti-RhD IgG product, we purified $\mathrm{RhD}$-specific IgG Abs from the approved product Rhophylac ${ }^{\circledR}$ (CSL Behring, King of Prussia, PA, USA) and analyzed the Abs' Fc glycosylation.

\section{Methods}

Purification of RhD-specific IgG Abs from Rhophylac $\mathbb{R}$

Total IgG from the commercial polyclonal anti-RhD IgG product Rhophylac ${ }^{\circledR}$ was purified using protein-G-sepharose (GE Healthcare, 
A

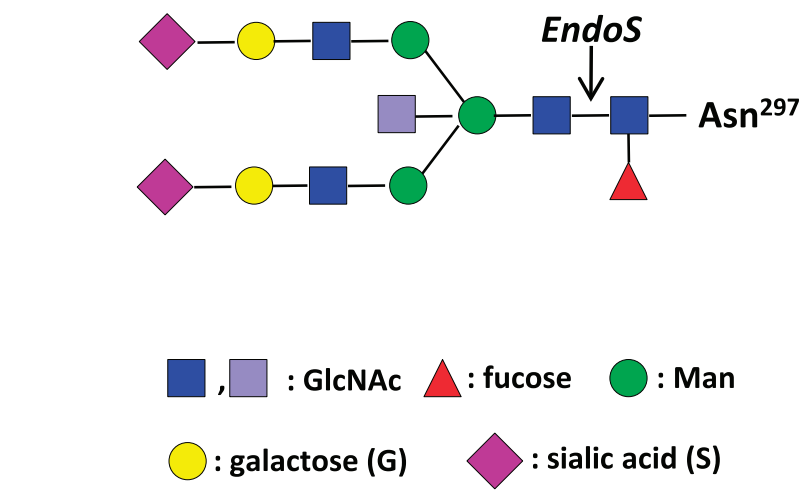

C

\section{$\lg G$ Fc Go}

$\square$ G0

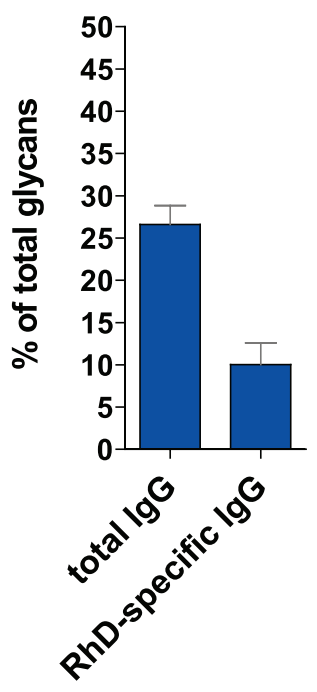

B

\section{IgG Fc glycosylation}

G0 $\square$ G1 $\square$ G2

$\square$ G1 S1 $\square$ G2 S1 $\square$ G2 S2

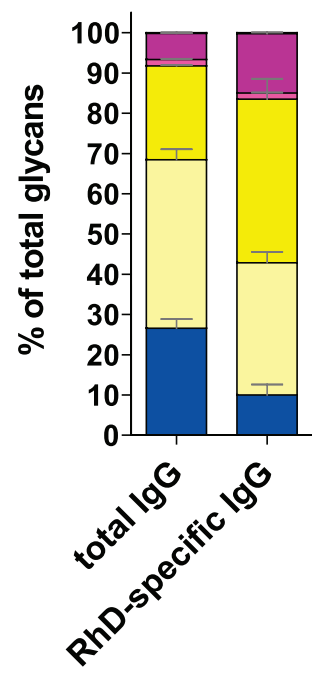

$\lg G$ Fc G2

G2

\section{IgG Fc S1 and S2}

$\square$ G1 S1

G2 S1 $\square$ G2 S2
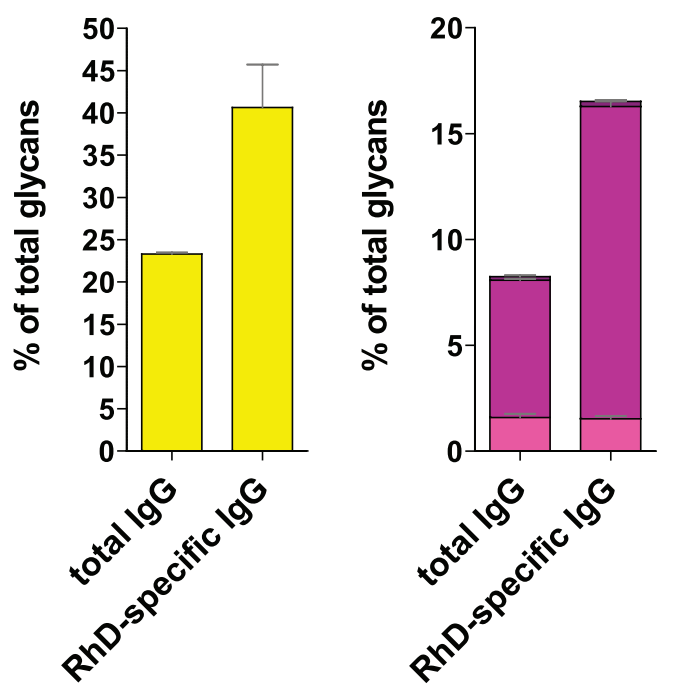

Figure 1. Polyclonal RhD-specific IgG Abs in Rhophylac $($ are sialylated. $(\mathbf{A})$ The biantennary lgG Fc glycan core structure, which is coupled to Asn 297, consists of two N-acetyl-glucosamines (GlcNAc; dark blue) and three mannoses (Man), which can be further decorated with fucose; bisecting GlcNAc (light blue) and terminal GlcNAc (dark blue), galactose (G) and sialic acid (S). (B and C) The purified total and RhD-specific IgG samples were hydrolyzed with EndoS and analyzed by MALDI-TOF MS. The cleavage site of EndoS is indicated by an arrow in (A). (B) The bar graph indicate the frequency of all glycan structures with 0,1 or 2 galactose (G) residues and 0,1 or 2 sialic acid (S) residues. The mean values with the standard error of the mean (SEM) from independent experiments are shown. (C) The bar graphs separately indicate the frequency of G0, G1, G2 and S1 and S2 glycan structures from the bar graph in (B). 
Fairfield, CT, USA). RhD-specific IgG Abs from the purified total IgG Abs of Rhophylac ${ }^{\circledR}$ were enriched using RhD-positive human erythrocytes. For this purpose, anonymous RhD-positive erythrocyte concentrates were obtained from the blood bank of the Charite - University Hospital Berlin. The erythrocyte concentrate was washed with $1 \mathrm{mM}$ EDTA in PBS. Next, $20 \mathrm{ml}$ of erythrocyte concentrate was diluted 1:1 with purified total IgG from Rhophylac $®$ in PBS, which contained approximately $600 \mu \mathrm{g}$ of $\mathrm{RhD}$-specific $\mathrm{IgG}$ Abs as indicated by the company, and was incubated for $2 \mathrm{~h}$ at $4^{\circ} \mathrm{C}$. The erythrocytes were then washed five times with PBS. Subsequently, RhD-specific IgG Abs were eluted with $0.15 \mathrm{M}$ glycine $\mathrm{pH}$ 3.0; neutralized with $1 \mathrm{M}$ Tris/ $\mathrm{HCl} \mathrm{pH} 9.0$ and dialyzed against PBS. Two independent RhD-specific IgG purifications (A and B) were done. Enrichment of the RhD-specific IgG Abs was verified by fluorescence-activated cell sorting (FACS) analysis. IgG Fc glycosylation was characterized through MALDI-TOF mass spectrometry (MS).

\section{FACS analysis}

Enrichment of the purified polyclonal RhD-specific IgG Abs was verified by FACS analysis (FACS Calibur with CellQuest Pro software, version 6.0 (BD Biosciences, Franklin Lakes, NJ, USA)). RhD-positive human RBCs were stained with $260 \mu \mathrm{g} / \mathrm{ml}$ of total $\mathrm{IgG}$ from Rhophylac ${ }^{\circledR}$ (blue), $2 \mu \mathrm{g} / \mathrm{ml}$ purified $\mathrm{RhD}$-specific IgGs (black) or $2 \mu \mathrm{g} / \mathrm{ml}$ of total IgG from Rhophylac ${ }^{\circledR}$ (red) and an anti-human IgG APC-coupled secondary Ab (\#550931; BD Biosciences) in cold PBS containing $0.5 \%$ bovine serum albumin (Sigma-Aldrich; St. Louis, MO, USA). The stained cells were gated on the main erythrocyte population in a FSC/SSC blot to exclude fragments and aggregates and analyzed in an anti-human IgG (APC) histogram. The data were analyzed with FlowJo 7.2.5 from Tree Star, Inc. Ashland, Oregon, USA. An overlay of different histograms, containing the analysis of the RhD-specific IgG Abs from purification A, is shown in Supplementary figure 1. The FCS files can be found in the data files below.

\section{FACS analyses of purified RhD-specific IgG antibodies}

6 Data Files

http://dx.doi.org/10.6084/m9.figshare.761186

\section{Glycan analysis through MALDI-TOF MS}

The purified total and RhD-specific IgG samples were hydrolyzed with recombinantly expressed endoglycosidase $\mathrm{S}$ (EndoS) from Streptococcus pyogenes, an enzyme that hydrolyzes N-glycans only from the Fc portion of the IgG Abs, to prevent the analysis of glycans from pontential contaminating RBC proteins ${ }^{34}$. The resulting N-glycans were purified through solid-phase extraction using reversedphase C18 and graphitized carbon columns (Alltech, Deerfield, IL, USA), permethylated and further investigated by MALDI-TOF MS ${ }^{21}$. The spectra were recorded on an Ultraflex III mass spectrometer (Bruker Corporation, Billerica, MA, USA) equipped with a Smartbeam laser. Calibration was performed on a glucose ladder, and 2,5-dihydroxybenzoic acid (DHB) was used as the matrix. Spectra were recorded in reflector positive ionization mode and mass spectra from 3,000 laser shots were accumulated. The crude glycan analysis data of the two independent $\mathrm{RhD}$-specific IgG Ab purifications $\mathrm{A}$ and $\mathrm{B}$ can be found in the data files below.

\section{MALDI-TOF MS glycan analysis of RhD-specific IgG antibodies (crude data)}

6 Data Files

http://dx.doi.org/10.6084/m9.figshare.761185

\section{Results and discussion}

To assess the Fc galactosylation and sialylation of RhD-specific IgG $\mathrm{Abs}$ in a commercially available polyclonal anti-RhD IgG product, we purified RhD-specific IgG Abs from Rhophylac ${ }^{\circledR}$ and analyzed the Abs' Fc glycosylation (Figure 1, Supplementary figure 1 and Supplementary figure 2 and the data files). We found that the purified polyclonal RhD-specific IgG Abs were even more galactosylated and sialylated than the total Rhophylac ${ }^{\circledR} \operatorname{IgG}$ Abs (Figure 1, Supplementary figure 1 and Supplementary figure 2 and the data files), which are comparable to total IgG Abs in immunosuppressive IVIG. The injection of RhD-positive RBCs into RhDnegative men obviously induced no pathogenic immune response. Comparable results have recently been generated by analyzing allergen-specific human IgG Abs after successful allergen-specific immunotherapy for birch pollen allergy ${ }^{21}$. Together, these results further indicate that tolerance induction induces mainly galactosylated and sialylated $\operatorname{IgG}$ Abs that have the potential to inhibit pathogenic immune responses via $\mathrm{ICs}^{21-24}$.

These results strongly suggest that only galactosylated and sialylated, immunosuppressive monoclonal RhD-specific $\operatorname{IgG}$ Abs can be substituted for polyclonal anti-RhD IgG products to inhibit pathogenic allo-immunity in RhD-negative pregnant woman. Low fucosylated, low agalactosylated and low sialylated $\mathrm{RhD}$-specific $\mathrm{IgG}$ Abs might not only enhance pro-inflammatory immune responses against RhD-positive fetal RBCs but also have the potential to attack RhD-positive fetal RBCs after transplacental passage.

\section{Author contributions}

AW contributed to the experimental design and carried out the research. MB helped with the glycan analysis. ME contributed to the experimental design and prepared the manuscript. All authors were involved in the revision of the draft manuscript and have agreed to the final content.

\section{Competing interests}

No competing interests were disclosed.

\section{Grant information}

AW and ME were supported by the German Research Foundation (DFG: EH221-5 and SFB/TR654 project C9). In addition ME was a fellow of the Claussen-Simon-Foundation, and supported by the Max Planck Institute for Infection Biology, Berlin, Germany and by additional DFG grants (RTG1727 associated project 16, 
IRTG1911 project A4 and the cluster of excellence 306 "Inflammation at Interfaces" project K-TP2). MB was supported by the German Ministry of Research and Education (03IP511) and the Sonnefeld Foundation.
The funders had no role in study design, data collection and analysis, decision to publish, or preparation of the manuscript.

Acknowledgements

We thank Mattias Collin for support with EndoS.

\section{Supplementary figures}

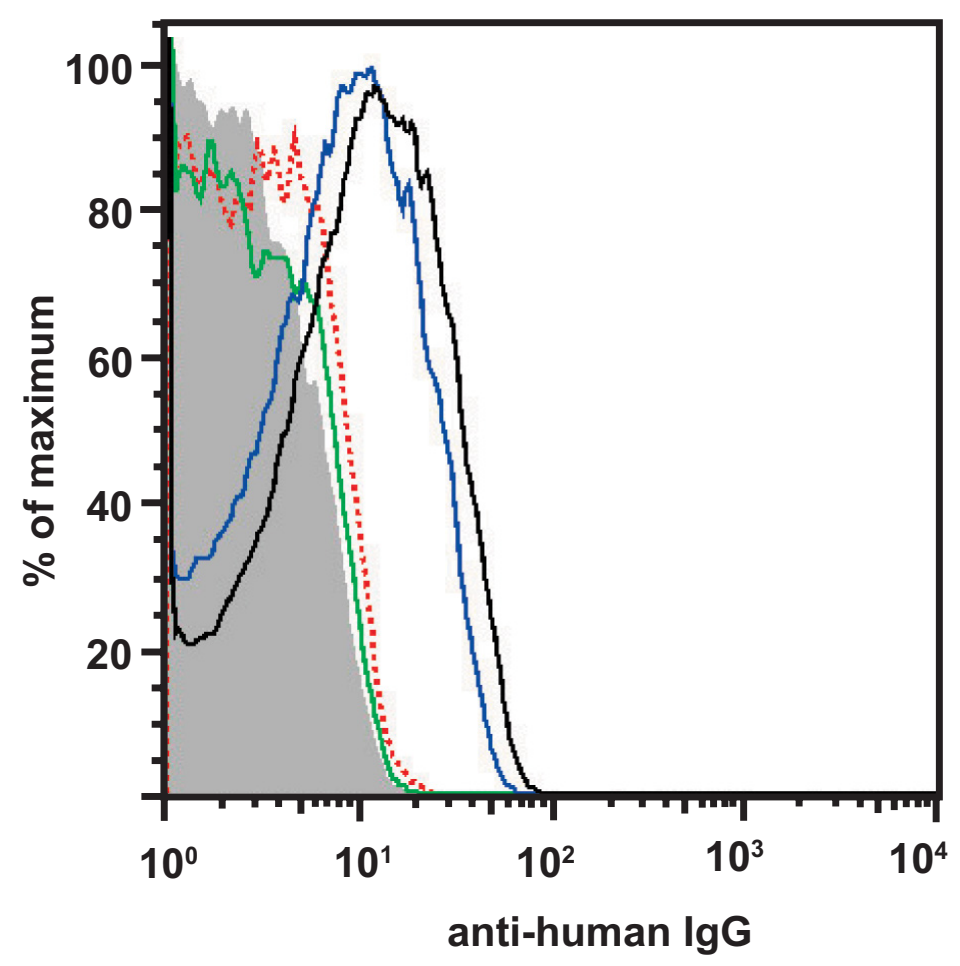

Supplementary figure 1. Verfication of the RhD-specific IgG purification. Purification of RhD-specific IgG Abs was verified by FACS analysis. RhD-positive human RBCs were stained with $260 \mu \mathrm{g} / \mathrm{ml}$ of total IgG from Rhophylac ${ }^{8}$ (blue), $2 \mu \mathrm{g} / \mathrm{ml}$ purified RhD-specific IgGs (black; purification A) or $2 \mu \mathrm{g} / \mathrm{ml}$ of total IgG from Rhophylac $\AA$ (red) and an anti-human IgG APC-coupled secondary Ab and analyzed by FACS analysis. The gray curve represents the unstained RBCs and the green curve represents the RBCs stained only with the secondary antibody. An overlay of different histograms, containing the analysis of the RhD-specific IgG Abs from purification A, is shown. 
A

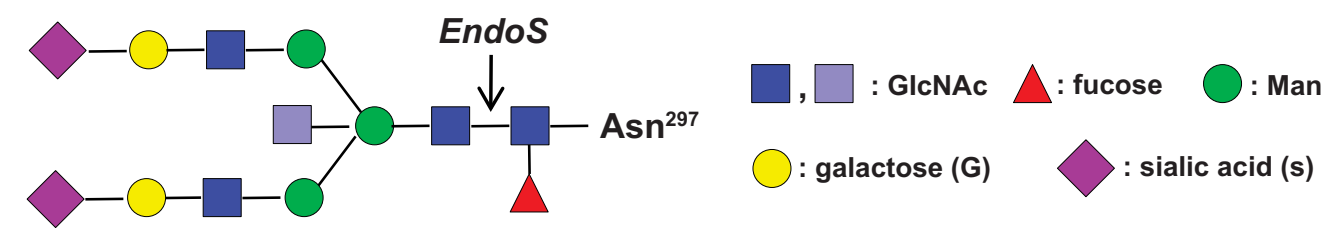

B

IgG Fc glycan structures (EndoS)

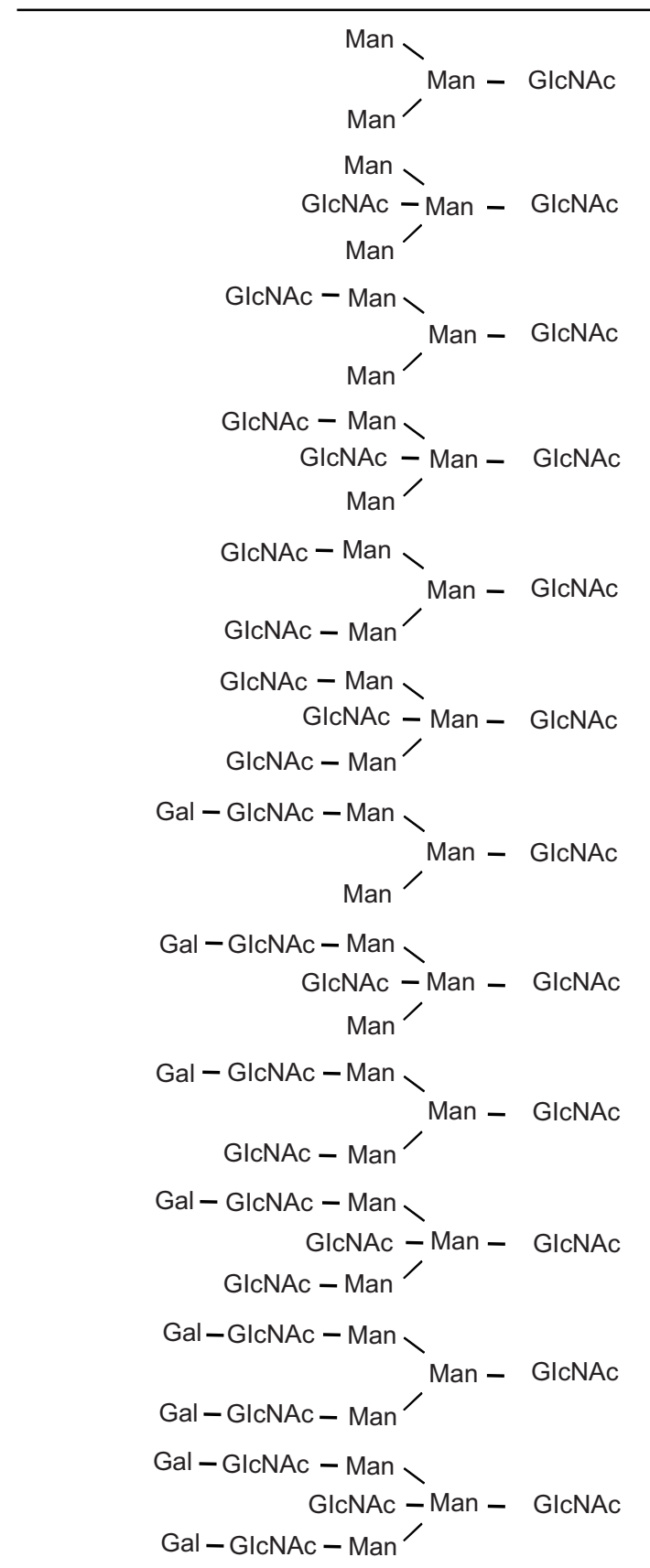

\section{mass $(\mathrm{m} / \mathrm{z})$ abbreviation}

927

1172

1417

1417

1662

1376

1621

1621

1866

1825

G2

Supplementary figure 2. Continued on next page. 
IgG Fc glycan structures (EndoS)

$$
\begin{aligned}
& \text { Neu5Ac-Gal - GlcNAc - Man } \\
& \text { Man - GlcNAc } \\
& \text { Man } \\
& \text { Neu5Ac - Gal - GlcNAc - Man } \\
& \text { GIcNAc - Man - GlcNAc } \\
& \text { Man' } \\
& \text { Neu5Ac - Gal - GlcNAc Man } \searrow \\
& \text { GIcNAc - Man / } \\
& \text { Neu5Ac - Gal - GlcNAc - Man } \\
& \text { GIcNAc - Man - GIcNAc } \\
& \text { GlcNAc - Man } \\
& \text { Neu5Ac - Gal - GlcNAc - Man } \\
& \text { Man - GlcNAc } \\
& \text { Gal - GlcNAc - Man / } \\
& \text { Neu5Ac - Gal - GlcNAc - Man } \searrow \\
& \text { GIcNAc - Man - GIcNAc } \\
& \text { Gal - GlcNAc - Man ' } \\
& \text { Neu5Ac - Gal - GlcNAc - Man } \searrow \\
& \text { Man - GlcNAc } \\
& \text { Neu5Ac - Gal - GlcNAc - Man ' } \\
& \text { Neu5Ac - Gal - GlcNAc - Man }> \\
& \text { GIcNAc - Man - GIcNAc } \\
& \text { Neu5Ac - Gal - GlcNAc - Man ' }
\end{aligned}
$$

Supplementary figure 2. EndoS-released glycan structures. (A) The biantennary IgG Fc glycan core structure, which is coupled to Asn 297 consists of two N-acetyl-glucosamines (GlcNAc; dark blue) and three mannoses (Man), which can be further decorated with fucose; bisecting GlcNAc (light blue) and terminal GlcNAc (dark blue), galactose (G, Gal) and sialic acid (N-acetylneuraminic acid (Neu5Ac), $\mathrm{S}$, Sial). The cleavage site of EndoS is indicated by an arrow. (B) The molecular mass ( $\mathrm{m} / \mathrm{z}$ ) of the possible Fc glycan structures (permethylated) released from Asn 297 upon EndoS treatment. 
1. Kumpel BM: Lessons learnt from many years of experience using anti-D in humans for prevention of RhD immunization and haemolytic disease of the fetus and newborn. Clin Exp Immunol. 2008; 154(1): 1-5. PubMed Abstract | Publisher Full Text | Free Full Text

2. Kumpel BM, Elson CJ: Mechanism of anti-D-mediated immune suppression--a paradox awaiting resolution? Trends Immunol. 2001; 22(1): 26-31. PubMed Abstract | Publisher Full Text

3. Kumpel BM: In vivo studies of monoclonal anti-D and the mechanism of immune suppression. Transfus Clin Biol. 2002; 9(1): 9-14. PubMed Abstract | Publisher Full Text

4. Kumpel BM: Efficacy of RhD monoclonal antibodies in clinical trials as replacement therapy for prophylactic anti-D immunoglobulin: more questions than answers. Vox Sang. 2007; 93(2): 99-111. PubMed Abstract | Publisher Full Text

5. Stott LM, Barker RN, Urbaniak SJ: Identification of alloreactive T-cell epitopes on the Rhesus D protein. Blood. 2000; 96(13): 4011-4019. PubMed Abstract

6. Hall AM, Cairns LS, Altmann DM, et al.: Immune responses and tolerance to the RhD blood group protein in HLA-transgenic mice. Blood. 2005; 105(5): 2175-2179.

PubMed Abstract | Publisher Full Text

7. Döbel T, Kunze A, Babatz J, et al.: Fc $\gamma R$ III (CD16) equips immature 6-sulfo LacNAc-expressing dendritic cells (slanDCs) with a unique capacity to handle IgG-complexed antigens. Blood. 2013; 121(18): 3609-3618.

PubMed Abstract | Publisher Full Text

8. Kumpel BM, Goodrick MJ, Pamphilon DH, et al.: Human Rh D monoclonal antibodies (BRAD-3 and BRAD-5) cause accelerated clearance of Rh D+ red blood cells and suppression of Rh D immunization in Rh D- volunteers. Blood. 1995; 86(5): 1701-1709.

PubMed Abstract

9. Shinkawa T, Nakamura K, Yamane N, et al.: The absence of fucose but not the presence of galactose or bisecting $\mathrm{N}$-acetylglucosamine of human IgG1 complex-type oligosaccharides shows the critical role of enhancing antibody-dependent cellular cytotoxicity. J Biol Chem. 2003; 278(5): 3466-3473.

PubMed Abstract | Publisher Full Text

10. Nimmerjahn F, Ravetch JV: Divergent immunoglobulin g subclass activity through selective Fc receptor binding. Science. 2005; 310(5753): 1510-1512. PubMed Abstract | Publisher Full Text

11. Ercan A, Cui J, Chatterton DE, et al:: Aberrant IgG galactosylation precedes disease onset, correlates with disease activity, and is prevalent in autoantibodies in rheumatoid arthritis. Arthritis Rheum. 2010; 62(8): 2239-2248.

PubMed Abstract | Publisher Full Text

12. Rademacher TW, Williams P, Dwek RA: Agalactosyl glycoforms of lgG autoantibodies are pathogenic. Proc Natl Acad Sci U S A. 1994; 91(13): 6123-6127.

PubMed Abstract | Publisher Full Text | Free Full Text

13. Parekh RB, Dwek RA, Sutton BJ, et al.: Association of rheumatoid arthritis and primary osteoarthritis with changes in the glycosylation pattern of total serum IgG. Nature. $1985 ; 316(6027)$ : 452-457. PubMed Abstract | Publisher Full Text

14. Scherer HU, van der Woude D, loan-Facsinay A, et al.: Glycan profiling of anticitrullinated protein antibodies isolated from human serum and synovial fluid. Arthritis Rheum. 2010; 62(6): 1620-1629. PubMed Abstract | Publisher Full Text

15. Rook GA, Steele J, Brealey R, et al:: Changes in IgG glycoform levels are associated with remission of arthritis during pregnancy. J Autoimmun. 1991; 4(5): 779-794.

PubMed Abstract | Publisher Full Text

16. Van Beneden K, Coppieters K, Laroy W, et al:: Reversible changes in serum immunoglobulin galactosylation during the immune response and treatment of inflammatory autoimmune arthritis. Ann Rheum Dis. 2009; 68(8): 1360-1365.

PubMed Abstract | Publisher Full Text

17. Kaneko Y, Nimmerjahn F, Ravetch JV: Anti-inflammatory activity of immunoglobulin G resulting from Fc sialylation. Science. 2006; 313(5787):
670-673.

PubMed Abstract | Publisher Full Text

18. Arnold JN, Wormald MR, Sim RB, et al.: The impact of glycosylation on the biological function and structure of human immunoglobulins. Annu Rev Immunol. 2007; 25: 21-50.

PubMed Abstract | Publisher Full Text

19. Nimmerjahn F, Ravetch JV: Anti-inflammatory actions of intravenous immunoglobulin. Annu Rev Immunol. 2008: 26: 513-533.

PubMed Abstract | Publisher Full Text

20. Anthony RM, Kobayashi T, Wermeling F, et al.: Intravenous gammaglobulin suppresses inflammation through a novel $\mathrm{T}(\mathrm{H}) 2$ pathway. Nature. 2011; 475(7354): 110-113

PubMed Abstract | Publisher Full Text | Free Full Text

21. Oefner CM, Winkler A, Hess $\mathrm{C}$, et al.: Tolerance induction with $\mathrm{T}$ cell-dependen protein antigens induces regulatory sialylated IgGs. J Allergy Clin Immunol. 2012; 129(6): 1647-1655.

PubMed Abstract | Publisher Full Text

22. Collin M, Ehlers M: The carbohydrate switch between pathogenic and mmunosuppressive antigen-specific antibodies. Exp Dermatol. 2013; 22(8): $511-4$

PubMed Abstract | Publisher Full Text

23. Hess C, Winkler A, Lorenz AK, et al:: T cell-independent B cell activation induces immunosuppressive sialylated IgG antibodies. J Clinical Invest. accepted.

24. Karsten CM, Pandey MK, Figge J, et al.: Anti-inflammatory activity of IgG1 mediated by Fc galactosylation and association of Fc gamma RIIB and dectin-1. Nat Med. 2012; 18(9): 1401-1406.

PubMed Abstract | Publisher Full Text | Free Full Text

25. Ackerman ME, Crispin M, Yu X, et al:: Natural variation in Fc glycosylation of HIV-specific antibodies impacts antiviral activity. J Clin Invest. 2013; 123(5): 2183-2192.

PubMed Abstract | Publisher Full Text | Free Full Text

26. Kumpel BM, Rademacher TW, Rook GA, et al:: Galactosylation of human IgG monoclonal anti-D produced by EBV-transformed B-lymphoblastoid cell lines is dependent on culture method and affects Fc receptor-mediated functional activity. Hum Antibodies Hybridomas. 1994; 5(3-4): 143-151. PubMed Abstract

27. Kumpel BM, Wang Y, Griffiths HL, et al:: The biological activity of human monoclonal IgG anti-D is reduced by beta-galactosidase treatment. Hum Antibodies Hybridomas. 1995; 6(3): 82-88.

PubMed Abstract

28. Sibéril S, de Romeuf $\mathrm{C}$, Bihoreau N, et al:: Selection of a human anti-RhD monoclonal antibody for therapeutic use: impact of IgG glycosylation on activating and inhibitory Fc gamma R functions. Clin Immunol. 2006; 118(2-3): 170-179

PubMed Abstract | Publisher Full Text

29. Beliard R, Waegemans T, Notelet D, et al:: A human anti-D monoclonal antibody selected for enhanced FcgammaRIII engagement clears RhD+ autologous red cells in human volunteers as efficiently as polyclonal anti-D antibodies. $\mathrm{Br} J$ Haematol. 2008; 141(1): 109-119.

PubMed Abstract | Publisher Full Text

30. PCT/FR2010/050376 (international publication number: WO/2010/100383) Anti-rhesus d monoclonal antibody. Reference Source

31. US 7931895 B2 patent "Monoclonal antibodies with enhanced ADCC function"; issued 2011

Reference Source

32. Yver A, Homery MC, Fuseau E, et al: Pharmacokinetics and safety of roledumab, a novel human recombinant monoclonal anti-RhD antibody with an optimized Fc for improved engagement of $\mathrm{FC} \gamma \mathrm{R} I I I$, in healthy volunteers. Vox Sang. 2012; 103(3): 213-222. PubMed Abstract | Publisher Full Tex

33. Beck A, Reichert JM: Marketing approval of mogamulizumab: a triumph for glyco-engineering. MAbs. 2012; 4(4): 419-425. PubMed Abstract | Publisher Full Text | Free Full Text

34. Collin M, Olsén A: Effect of SpeB and EndoS from Streptococcus pyogenes on human immunoglobulins. Infect Immun. 2001; 69(11): 7187-7189.

PubMed Abstract | Publisher Full Text | Free Full Text 


\section{Open Peer Review}

\section{Current Peer Review Status:}

\section{Version 1}

Reviewer Report 27 September 2013

https://doi.org/10.5256/f1000research.1852.r1718

(C) 2013 Karlsson M. This is an open access peer review report distributed under the terms of the Creative Commons Attribution License, which permits unrestricted use, distribution, and reproduction in any medium, provided the original work is properly cited.

\section{Mikael C. I. Karlsson}

Department of Medicine-Solna, Karolinska Institutet, Karolinska University Hospital Solna, Stockholm, Sweden

Anti-RhD therapy is one of the most successful antibody therapies ever invented and still we do not know how antibodies block Rh immunization. Recently, a novel level of regulation through alterations in glycosylation patterns has been started to be appreciated. This study is a good starting point to investigate if this mechanism of regulation by antibodies is involved. The glycosylation pattern found in the anti-RhD pool of antibodies suggests that an active tolerogenic pathway is involved and encourages further investigation.

Competing Interests: No competing interests were disclosed.

\section{I confirm that I have read this submission and believe that I have an appropriate level of expertise to confirm that it is of an acceptable scientific standard.}

Reviewer Report 23 September 2013

https://doi.org/10.5256/f1000research.1852.r1716

(C) 2013 McGaha T. This is an open access peer review report distributed under the terms of the Creative Commons Attribution License, which permits unrestricted use, distribution, and reproduction in any medium, provided the original work is properly cited.

\section{Tracy McGaha}

Cancer Immunology, Inflammation, and Tolerance Program, Georgia Regents University Cancer Center, Augusta, GA, USA

In the article "Anti-rhesus D prophylaxis..." by Winkler, Berger, and Ehlers the authors present data demonstrating enrichment of galactosylation and sialylation in the anti Rh-D fraction of 
Rhophylac. This study is well written with adequate discussion of methods. Moreover, the report builds on exciting recent findings that the pattern of glycosylation is an important determinant factor in the effector function of IgG providing mechanistic control of FcGR interactions and tolerogenic v.s. inflammatory immunity. Their results would suggest the therapeutic value of anti$\mathrm{RhD}$ therapy may lie in an active tolerogenic response rather than via clearance mechanisms, a theory which should be tested moving forward.

The title is a bit misleading as it suggests experimental evidence contained within the report demonstrates anti-RhD activity is due to glycosylation, a theorized outcome that has yet to be demonstrated. A revision to reflect this fact may be appropriate.

Otherwise, it is an exciting report pointing to a novel mechanism that may drive prophylactic antiRhD therapy.

Competing Interests: No competing interests were disclosed.

I confirm that I have read this submission and believe that I have an appropriate level of expertise to confirm that it is of an acceptable scientific standard.

Author Response 23 Oct 2013

André Winkler, German Rheumatism Research Center (DRFZ), Leibniz Institute, Berlin, Germany

Dear Tracy,

many thanks for reviewing our manuscript.

I agree that the title is a bit misleading. I would propose to slightly change it to: "Anti-rhesus $D$ prophylaxis in pregnant women is might based on sialylated IgG antibodies"

This statement is based on the fact that AntiD IgG are highly sialylated and the immunoregulatory properties of sialylated IgG has been shown previously by us and by others.

Do you agree?

Competing Interests: I am the author

Reviewer Response 28 Oct 2013

Tracy McGaha, Georgia Regents University Cancer Center, Augusta, GA, USA

Dear Dr Winkler,

I think the proposed revision is appropriate and acceptable.

Regards, 
Tracy McGaha.

Competing Interests: none

The benefits of publishing with F1000Research:

- Your article is published within days, with no editorial bias

- You can publish traditional articles, null/negative results, case reports, data notes and more

- The peer review process is transparent and collaborative

- Your article is indexed in PubMed after passing peer review

- Dedicated customer support at every stage

For pre-submission enquiries, contact research@f1000.com 